\title{
Mental Toughness and Emotional Maturity in Basketball Performance: Identifying Performance Indicators
}

\author{
Davinder Singh \\ Department of Physical Education, D.A.V. College, Amritsar, India \\ Tel: 91-98558-10848_E-mail: ds_rajput87@yahoo.in
}

Received: August 5, 2015 Accepted: August 27, 2015 Published: August 28, 2015

doi:10.5296/elr.v1i2.8130 URL: http://dx.doi.org/10.5296/elr.v1i2.8130

\begin{abstract}
The present study was aimed to indentify the mental toughness and emotional maturity among basketball players. For this purpose, sixty female basketball players of 20 to 25 years of age were selected. They were further divided into three groups; (i.e., $\mathrm{N}_{1}=20$; District, $\mathrm{N}_{2}=20$; State and $\mathrm{N}_{3}=20$ National). To determine level of Mental Toughness among subjects, Mental Toughness, constructed by Goldberg et al. (1998) was administered. To determine level of Emotional Maturity among subjects, Emotional Maturity Scale constructed by Singh and Bhargava's (1988) was administered. One way Analysis of Variance (ANOVA) was employed to find out the intra-group differences. The findings show that no significant differences were found among female basketball players on the sub-variables of Mental Toughness. Conculdingly from the above findings that insignificant differences were present among female basketball players on the sub-variables of Emotional Maturity.
\end{abstract}

Keywords: Mental toughness, Emotional maturity, Basketball

\section{Introduction}

Sport psychology specialist work with athletes who hold extensively differing values and beliefs about their sporting and everyday life. Psychological variables are universally acknowledged as being foremost provider to generous success in sports J. Singh and S. Singh (2011). Therefore the athletic ability and physical fitness are understandable parts of that list, but another variable that commonly surfaces when these top mark athletes and programs are studied is mental toughness (Ness, 1977). Clough et al. (2002) explain that mentally strong individual have a high level of an unshakable faith and sense of self-belief which pedals the goals, then the particular individuals be able to comparatively unaltered by misfortune and 
struggle. In team game sports psychological issues play a crucial role for enhancing performance and maximizing health benefits of athletes. So many Scientific studies evidence shows that mere participation in sports can prove to be psychological asset and also further helpful in lifelong activities regardless of whether the participation has been Competition oriented (Matsumoto \& Konno, 2005). While considering the paramount importance of psychological variables with regard to combat sports the investigators focused to analyze the major role of mental toughness and emotional maturity in elite basketball performance.

\section{Methods}

\subsection{Participants}

For this purpose, sixty female basketball players of 20 to 25 years of age were selected. They were further divided into three groups; (i.e., $\mathrm{N}_{1}=20$; District, $\mathrm{N}_{2}=20$; State and $\mathrm{N}_{3}=20$ National).

\subsection{Tools}

\begin{tabular}{llll}
\hline Sr.no & Tools & Authors & Year \\
\hline 1. & Mental Toughness & Goldberg & 1998 \\
2. & Emotional Maturity & Singh and Bhargava's & 1988 \\
\hline
\end{tabular}

\section{Statistical Analysis}

One Way Analysis of Variance (ANOVA) was employed to compare the three groups of basketball. For testing the hypotheses, the level of significance was set at 0.05 .

\section{Results}

Table 1. Significant differences in the results among Female Basketball Players with regard to mental toughness on the sub-variable reboundability

\begin{tabular}{|c|c|c|c|c|c|}
\hline $\begin{array}{ll}\text { Source } & \text { of } \\
\text { Variation } & \end{array}$ & $\begin{array}{l}\text { Sum of } \\
\text { Squares }\end{array}$ & $\begin{array}{l}\text { Degree } \\
\text { Freedom }\end{array}$ & $\begin{array}{l}\text { Mean } \\
\text { Square }\end{array}$ & F-value & $\begin{array}{l}\text { P-value } \\
\text { (Sig.) }\end{array}$ \\
\hline Between Groups & 1.233 & 2 & .617 & .485 & .618 \\
\hline Within Groups & 72.500 & 57 & 1.272 & & \\
\hline Total & 73.733 & 59 & & & \\
\hline
\end{tabular}

*Significant at 0.05 .

It can be seen from Table 1 that insignificant differences were found with regard to the sub-variable Reboundability among District, State and National female basketball players as the P-value (Sig.) .618 was found higher than the 0.05 level of significance $(p>0.05)$. 
Table 2. Significant differences in the results among Female Basketball Players with regard to mental toughness on the sub-variable ability to handle pressure

\begin{tabular}{|c|c|c|c|c|c|}
\hline $\begin{array}{l}\text { Source of } \\
\text { Variation }\end{array}$ & $\begin{array}{l}\text { Sum of } \\
\text { Squares }\end{array}$ & $\begin{array}{l}\text { Degree of } \\
\text { Freedom }\end{array}$ & Mean Square & F-value & $\begin{array}{l}\text { P-value } \\
\text { (Sig.) }\end{array}$ \\
\hline Between Groups & .100 & 2 & .050 & .050 & .952 \\
\hline Within Groups & 57.500 & 57 & 1.009 & & \\
\hline Total & 57.600 & 59 & & & \\
\hline
\end{tabular}

*Significant at 0.05 .

It can be seen from Table 2 that insignificant differences were found with regard to the sub-variable Ability to Handle Pressure among District, State and National female basketball players as the P-value (Sig.) .952 was found higher than the 0.05 level of significance $(\mathrm{p}>0.05)$.

Table 3. Significant differences in the results among female basketball players with regard to mental toughness on the sub-variable concentration

\begin{tabular}{lllllll}
\hline $\begin{array}{l}\text { Source of } \\
\text { Variation }\end{array}$ & $\begin{array}{l}\text { Sum } \\
\text { Squares }\end{array}$ & $\begin{array}{l}\text { of } \\
\text { Freedom }\end{array}$ & $\begin{array}{l}\text { Degree } \\
\text { of }\end{array}$ & Mean Square & F-value & $\begin{array}{l}\text { P-value } \\
\text { (Sig.) }\end{array}$ \\
\hline Between Groups & 2.633 & 2 & 1.317 & 1.032 & .363 \\
Within Groups & 72.700 & 57 & 1.275 & & \\
Total & 75.333 & 59 & & & \\
\hline
\end{tabular}

*Significant at 0.05 .

It can be seen from Table 3 that insignificant differences were found with regard to the sub-variable Concentration among District, State and National female basketball players as the P-value (Sig.) .363 was found higher than the 0.05 level of significance $(p>0.05)$.

Table 4. Significant differences in the results among female basketball players with regard to mental toughness on the sub-variable confidence

\begin{tabular}{llllll}
\hline $\begin{array}{l}\text { Source of } \\
\text { Variation }\end{array}$ & $\begin{array}{l}\text { Sum of } \\
\text { Squares }\end{array}$ & Degree of Freedom & Mean Square & $\begin{array}{l}\text { F-value } \\
\text { P-value } \\
\text { (Sig.) }\end{array}$ \\
\hline Wetween Groups & 1.900 & 2 & .950 & .985 & .380 \\
Total & 54.950 & 57 & .964 & & \\
\hline
\end{tabular}

*Significant at 0.05 . 


\section{Macrothink \\ Education and Linguistics Research \\ ISSN 2377-1356 \\ 2015, Vol. 1, No. 2}

It can be seen from Table 4 that insignificant differences were found with regard to the sub-variable Confidence among District, State and National female basketball players as the P-value (Sig.) . 380 was found higher than the 0.05 level of significance $(p>0.05)$.

Table 5. Significant differences in the results among female basketball players with regard to mental toughness on the sub-variable motivation

\begin{tabular}{llllll}
\hline $\begin{array}{l}\text { Source of } \\
\text { Variation }\end{array}$ & $\begin{array}{l}\text { Sum of } \\
\text { Squares }\end{array}$ & Degree of Freedom & Mean Square & F-value & $\begin{array}{l}\text { P-value } \\
\text { (Sig.) }\end{array}$ \\
\hline Between Groups & 4.133 & 2 & & 1.874 & .163 \\
Within Groups & 62.850 & 57 & 1.103 & & \\
Total & 66.983 & 59 & & & \\
\hline
\end{tabular}

*Significant at 0.05 .

It can be seen from Table 5 that insignificant differences were found with regard to the sub-variable Motivation among District, State and National female basketball players as the P-value (Sig.) .163 was found higher than the 0.05 level of significance $(p>0.05)$.

Table 6. Significant differences in the results among female basketball players with regard to overall mental toughness

\begin{tabular}{|c|c|c|c|c|c|}
\hline $\begin{array}{l}\text { Source of } \\
\text { Variation }\end{array}$ & $\begin{array}{l}\text { Sum of } \\
\text { Squares }\end{array}$ & Degree of Freedom & Mean Square & F-value & $\begin{array}{l}\text { P-value } \\
\text { (Sig.) }\end{array}$ \\
\hline Between Groups & 2.433 & 2 & 1.217 & .306 & .737 \\
\hline Within Groups & 226.300 & 57 & 3.970 & & \\
\hline Total & 228.733 & 59 & & & \\
\hline
\end{tabular}

*Significant at 0.05 .

It can be seen from Table 6 that insignificant differences were found with regard to the variable Overall Mental Toughness among female basketball players District, State and National as the P-value (Sig.) .737 was found higher than the 0.05 level of significance ( $p>$ $0.05)$. 
Table 7. Significant differences in the results among female basketball players with regard to emotional maturity on the sub-variable emotional unstability

\begin{tabular}{llllll}
\hline $\begin{array}{l}\text { Source of } \\
\text { Variation }\end{array}$ & $\begin{array}{l}\text { Sum of } \\
\text { Squares }\end{array}$ & Degree of Freedom & Mean Square & F-value & $\begin{array}{l}\text { P-value } \\
\text { (Sig.) }\end{array}$ \\
\hline Between Groups & 13.333 & 2 & 6.667 & .224 & .800 \\
Within Groups & 1696.600 & 57 & 29.765 & & \\
Total & 1709.933 & 59 & & & \\
\hline
\end{tabular}

*Significant at 0.05 .

It can be seen from Table 7 that insignificant differences were found with regard to the sub-variable Emotional Unstability among District, State and National female basketball players as the P-value (Sig.) .800 was found higher than the 0.05 level of significance ( $p$ > $0.05)$.

Table 8. Significant differences in the results among female basketball players with regard to emotional maturity on the sub-variable emotional regression

\begin{tabular}{llllll}
\hline $\begin{array}{l}\text { Source of } \\
\text { Variation }\end{array}$ & $\begin{array}{l}\text { Sum of } \\
\text { Squares }\end{array}$ & Degree of Freedom & Mean Square & F-value & $\begin{array}{l}\text { P-value } \\
\text { (Sig.) }\end{array}$ \\
\hline Between Groups & 163.333 & 2 & 81.667 & 3.623 & .333 \\
Within Groups & 1284.850 & 57 & 22.541 & & \\
Total & 1448.183 & 59 & & & \\
\hline
\end{tabular}

*Significant at 0.05 .

It can be seen from Table 8 that insignificant differences were found with regard to the sub-variable Emotional Regression among District, State and National female basketball players as the P-value (Sig.) .333 was found higher than the 0.05 level of significance $(\mathrm{p}>0.05)$.

Table 9. Significant differences in the results among female basketball players with regard to emotional maturity on the sub-variable social maladjustment

\begin{tabular}{llllll}
\hline $\begin{array}{l}\text { Source of } \\
\text { Variation }\end{array}$ & $\begin{array}{l}\text { Sum of } \\
\text { Squares }\end{array}$ & Degree of Freedom & Mean Square & F-value & $\begin{array}{l}\text { P-value } \\
\text { (Sig.) }\end{array}$ \\
\hline Between Groups & 30.000 & 2 & 15.000 & .613 & .545 \\
Within Groups & 1395.250 & 57 & 24.478 & & \\
Total & 1425.250 & 59 & & & \\
\hline
\end{tabular}

*Significant at 0.05 . 


\section{Macrothink \\ Education and Linguistics Research \\ ISSN 2377-1356 \\ 2015, Vol. 1, No. 2}

It can be seen from Table 9 that insignificant differences were found with regard to the sub-variable Social Maladjustment among District, State and National female basketball players as the P-value (Sig.) .545 was found higher than the 0.05 level of significance $(\mathrm{p}>0.05)$.

Table 10. Significant differences in the results among female basketball players with regard to emotional maturity on the sub-variable personality disintegration

\begin{tabular}{lllclc}
\hline $\begin{array}{l}\text { Source of } \\
\text { Variation }\end{array}$ & $\begin{array}{l}\text { Sum } \\
\text { Squares }\end{array}$ & $\begin{array}{l}\text { of } \\
\text { Fegreedom }\end{array}$ & $\begin{array}{l}\text { of } \\
\text { Frean } \\
\text { Square }\end{array}$ & F-value & $\begin{array}{l}\text { P-value } \\
\text { (Sig.) }\end{array}$ \\
\hline Between Groups & 10.800 & 2 & 5.400 & .176 & .839 \\
Within Groups & 1748.050 & 57 & 30.668 & & \\
Total & 1758.850 & 59 & & & \\
\hline
\end{tabular}

*Significant at 0.05 .

It can be seen from Table 10 that insignificant differences were found with regard to the sub-variable Personality Disintegration among District, State and National female basketball players as the P-value (Sig.) .839 was found higher than the 0.05 level of significance ( $p$ > $0.05)$.

Table 11. Significant differences in the results among female basketball players with regard to emotional maturity on the sub-variable lack of independence

\begin{tabular}{lllllc}
\hline $\begin{array}{l}\text { Source of } \\
\text { Variation }\end{array}$ & $\begin{array}{l}\text { Sum of } \\
\text { Squares }\end{array}$ & Degree of Freedom & Mean Square & F-value & $\begin{array}{l}\text { P-value } \\
\text { (Sig.) }\end{array}$ \\
\hline Between Groups & .533 & 2 & & .267 & .016 \\
Within Groups & 942.400 & 57 & 16.533 & & .984 \\
Total & 942.933 & 59 & & & \\
\hline
\end{tabular}

*Significant at 0.05 .

It can be seen from Table 11 that insignificant differences were found with regard to the sub-variable Lack of Independence among District, State and National female basketball players as the P-value (Sig.) .984 was found higher than the 0.05 level of significance ( $p>$ $0.05)$. 
Table 12. Significant differences in the results among female basketball players with regard to emotional maturity

\begin{tabular}{llllll}
\hline $\begin{array}{l}\text { Source of } \\
\text { Variation }\end{array}$ & $\begin{array}{l}\text { Sum of } \\
\text { Squares }\end{array}$ & Degree of Freedom & Mean Square & F-value & $\begin{array}{l}\text { P-value } \\
\text { (Sig.) }\end{array}$ \\
\hline Between Groups & 264.033 & 2 & 132.017 & .307 & .737 \\
Within Groups & 24546.900 & 57 & 430.647 & & \\
Total & 24810.933 & 59 & & & \\
\hline
\end{tabular}

*Significant at 0.05 .

It can be seen from Table 12 that insignificant differences were found with regard to the variable Emotional Maturity among District, State and National female basketball players as the P-value (Sig.) . 737 was found higher than the 0.05 level of significance ( $p>0.05)$.

\section{Practical Application}

The study will be considerably helpful to comprehend the Mental Toughness and Emotional Maturity level existing among female basketball players. The sports psychologists and coaches working with these areas will drive benefit from the findings of the present research and they can integrate the Mental Toughness and Emotional Maturity variables in their training schedule from the very initial stages.

\section{Conclusion}

Summarizing from the above findings we can say that no significant differences were found among female basketball players on the sub-variables of Mental Toughness. Conculdingly from the above findings that insignificant differences were present among female basketball players on the sub-variables of Emotional Maturity.

\section{References}

Clough, P., Earle, K., \& Sewell, D. (2002). Solutions in Sport Psychology, Mental Toughness: The Concept and its Measurement. In I. Cockerill (Ed.), 32-45.

Connaughton, D., Wadey, R., Hanton, S., \& Jones, G. (2008). The Development and Maintenance of Mental Toughness: Perceptions of Elite Performers. Journal of Sports Sciences, 26(1), 83-95. http://dx.doi.org/10.1080/02640410701310958

Goldberg, A. S. (1998). Sports Slump Busting: 10 Steps to Mental Toughness and Peak Performance. Champaign, IL: Human Kinetics.

Matsumoto, D., \& Konno, J. (2005). The Relationship between Adolescents' Participation in Judo, Quality of Life, and Life Satisfaction. Budogaku Kenkyu, 38(1), 13-26.

Ness, J. (1997). Are You Training your Mental Game or Just Thinking About it? Technique, 17,9 .

Singh, J., \& Singh, S. (2011). Status of Emotional Maturity among Under Graduate College Students: A Comparative Analysis. Indian J. Sports Sci. Phys. Educ, 21, 9-18. 
Singh, Y., \& Bhargava, M. (1980). Manual for Emotional Maturity Construct and Standardized Emotional Maturity Scale. National Psychological Corporation, 4/230, Kachari Gate, Agra, India.

\section{Copyright Disclaimer}

Copyright reserved by the author(s).

This article is an open-access article distributed under the terms and conditions of the Creative Commons Attribution license (http://creativecommons.org/licenses/by/3.0/). 